\title{
Anoectochilus formosanus (Orchidaceae), a new record for Hong Kong
}

\author{
Kumar P.* \& S.W. Gale \\ Kadoorie Farm and Botanic Garden, Lam Kam Road, Lam Tsuen, Tai Po, New Territories, \\ Hong Kong S.A.R., Peoples Republic of China \\ *E-mail: pkumar@kfbg.org
}

\begin{abstract}
The jewel orchid Anoectochilus formosanus Hayata, until now known only from Japan and Taiwan, is reported from Hong Kong for the first time. A detailed description, colour plate, line drawings and notes on ecology, distribution and conservation status are provided.
\end{abstract}

Keywords: Anoectochilus roxburghii, Conservation assessment, Indo-Burma Biodiversity Hotspot, Jewel orchid.

\section{Introduction}

Hong Kong, lying at the easternmost margin of the Indo-Burma Biodiversity Hotspot (IBBH), harbors 133 documented species of orchids (Gale et al., 2014), which constitutes nearly $6 \%$ of the Hong Kong flora and nearly $8 \%$ of all orchids known in the flora of China (Zhou et al., 2016), within an area of just $1,108 \mathrm{~km}^{2}$. This tally has risen steadily since botanical exploration of the territory commenced in 1816, with Reichenbach (1855) enumerating 23 species, Dunn and Tutcher (1912) 66, Herklots (1937) 75, Hu (1977) 109, Siu (2000) 125, Barretto et al. (2011) 126, and Kumar et al. (2014) 130 - a rate of $c .7$ species added every 10 years. Here we report on another newly recorded orchid for Hong Kong, bringing the total to 134.

Plants belonging to the jewel orchid genus Anoectochilus were discovered growing among boulders in a remote mountain stream in October

Received: 26.02.2020; Revised \& Accepted: 10.04.2020

Published Online: 30.06.2020
2018, with the texture and colouration of their leaves distinguishing them from $A$. roxburghii (Wall.) Lindl., a well-known Hong Kong native (Barretto et al., 2011). When they bloomed a week later, floral morphology suggested an affiliation to A. formosanus Hayata, a species known only from Taiwan (Su, 2000) and the southern Ryukyu Islands of Japan (Garay \& Sweet, 1974; Iwatsuki et al., 2016). A few flowers were collected with permission from the Agriculture, Fisheries and Conservation Department (AFCD) of the Hong Kong Government a year later, and these were critically compared with published descriptions provided by Hayata (1914) and Chen et al. (2009), as well as with images of Taiwanese herbarium material available online (http://taif.tfri.gov.tw/), allowing us to confirm the field identification. A detailed description, line drawings, a colour plate and notes on ecology and conservation status are presented below.

Anoectochilus formosanus Hayata, Icon. P1. Formosan. 4: 101. 1914. Type: TAIWAN (without precise locality), from cultivation in Taihoku, 03.1914, B. Hayata s.n. (not found). Anoectochilus tetsuoi Ohwi ex Hatus. \& T. Amano, Fl. Okinawa 148. 1958, nom. nud.

Figs. $1 \& 2$

Vernacular names: Taiwan jewel orchid; 台湾银线兰 (tai wan yin xian lan in Mandarin); 台灣 金線蓮 (tai wan gam sin lin in Cantonese); キバナシュスラン (kibana-shusuran in Japanese).

Plants erect, up to $25 \mathrm{~cm}$ tall. Rhizomes creeping, ascending, terete, $0.3-0.5 \mathrm{~cm}$ diam., bearing thick hairy roots. Leaves $2-5$, clustered at the base of the 


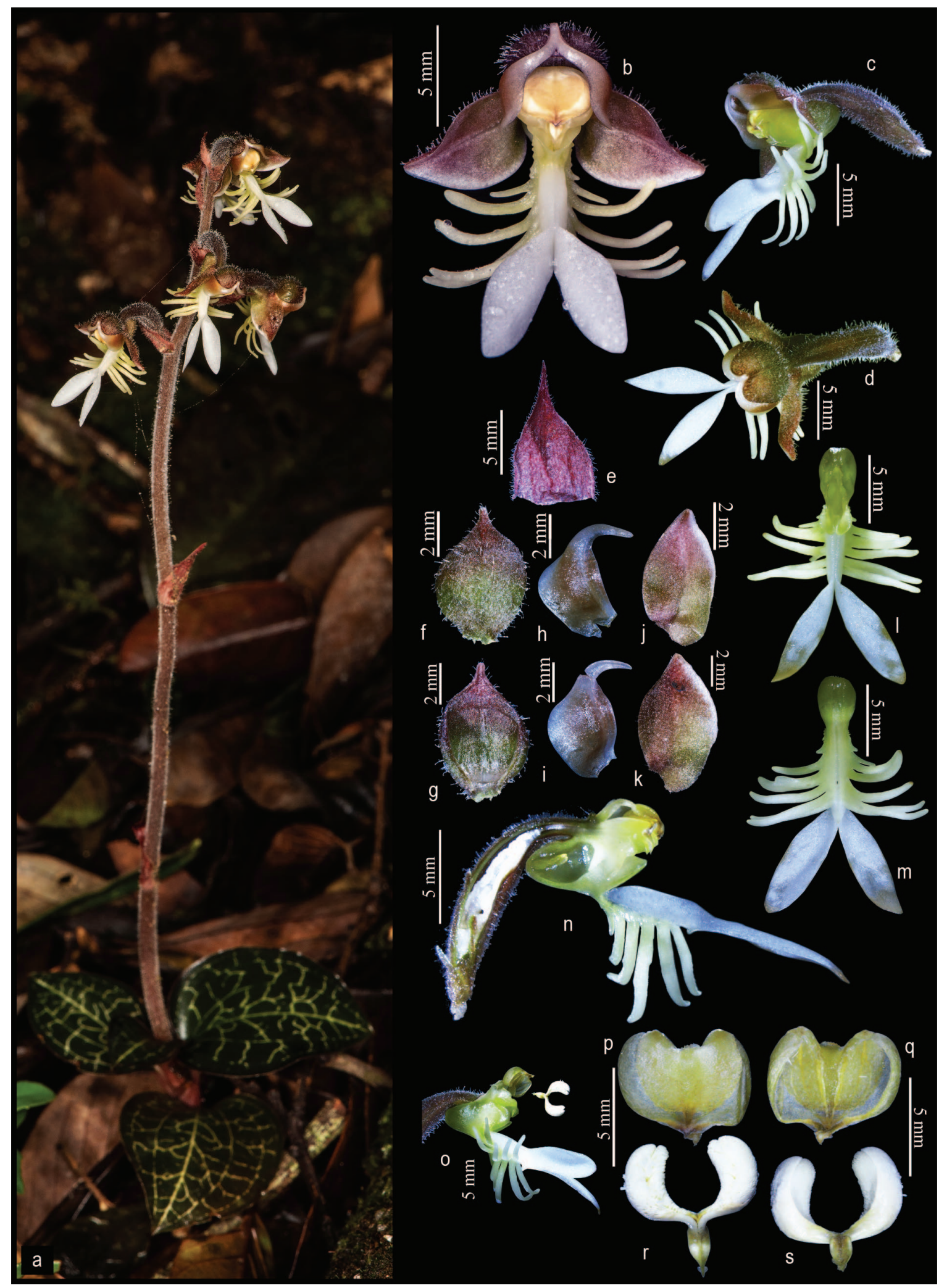

Fig. 1. Anoectochilus formosanus Hayata: a. Habit; b. Flower-front view; c. Flower-side view; d. Flower-top view; e. Bract; f. Dorsal sepaldorsal view; g. Dorsal sepal-ventral view; h. Petal-dorsal view; i. Petal-ventral view; j. Lateral sepal-dorsal view; k. Lateral sepal-ventral view; I. Labellum with spur-dorsal view; m. Labellum with spur-ventral view; n. Flower-vertical section; 0. Labellum and column-side view; p. Anther cap-dorsal view; q. Anther cap-ventral view; r. Pollinarium-dorsal view; s. Pollinarium-ventral view (from P. Kumar12215; photos by Pankaj Kumar). 

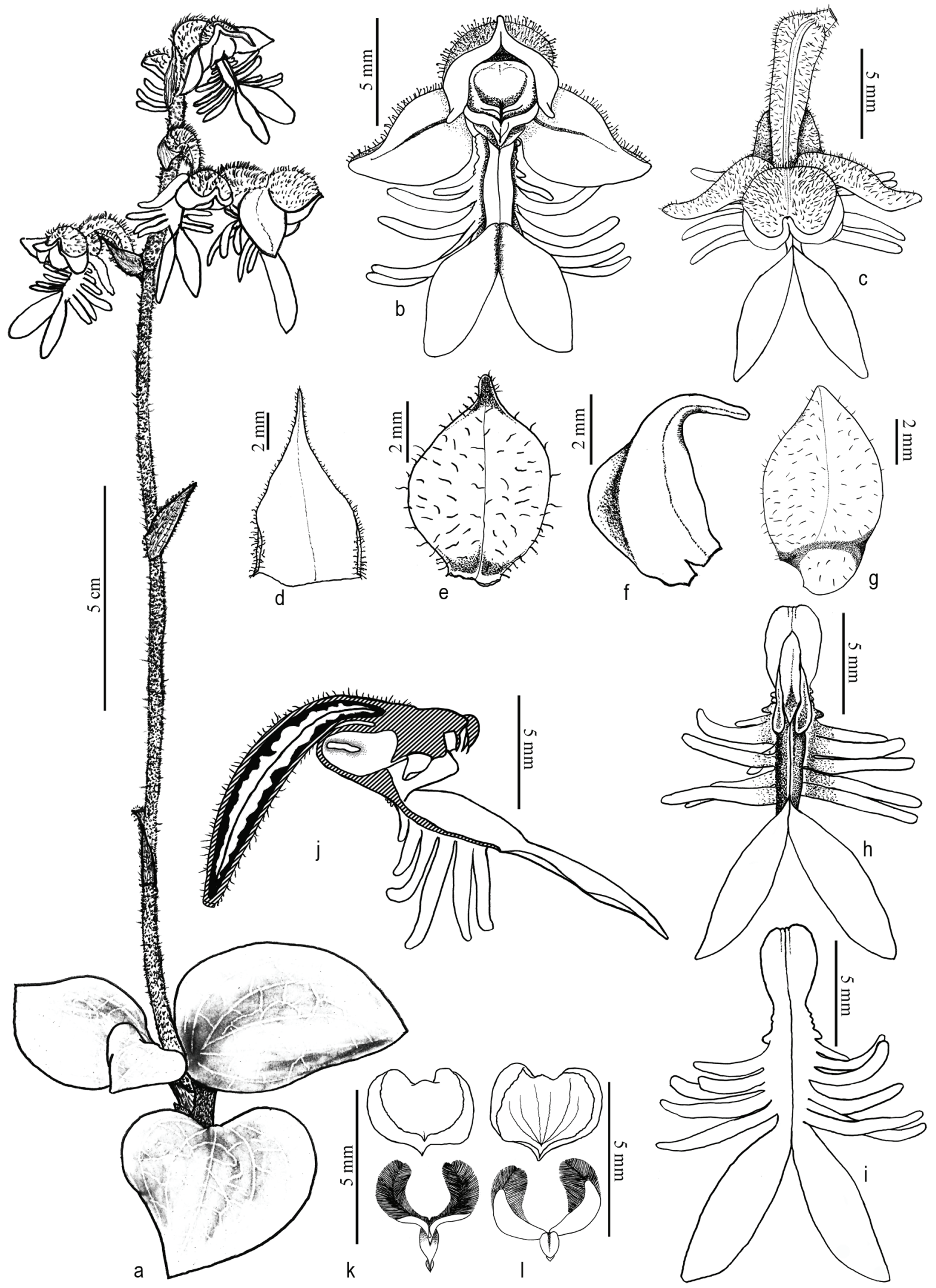

Fig. 2. Anoectochilus formosanus Hayata: a. Habit; b. Flower-front view; c. Flower-top view; d. Bract; e. Dorsal sepal; f. Petal; g. Lateral sepal; h. Labellum with spur-dorsal view; i. Labellum with spur-ventral view; j. Flower-vertical section; k. Pollinarium and anther cap-dorsal view; I. Pollinarium and anther cap-ventral view (from P. Kumar 12215; illustrations by Pankaj Kumar). 
plant; petioles $1.5-2.5 \times 0.8-1 \mathrm{~cm}$, bright reddishbrown, sheathing at base; lamina ovate, $2-5 \times 2-$ $3.5 \mathrm{~cm}$, acute at apex, margins pale white, reddishgreen dorsally, dark green with silver-white markings ventrally. Peduncles erect, terete, slender, up to 3-noded, hairy, pale reddish-brown, up to $20 \mathrm{~cm}$ long, bearing $2-3$ sterile bracts; sterile bracts ovate, $1-1.5 \times 0.8-1 \mathrm{~cm}$, acute at apex, membranous, bright red-brown. Floral rachis 3$5.5 \mathrm{~cm}$ long, bearing up to 7 laxly arranged flowers; floral bracts ovate, $1-1.5 \times 0.6-0.8 \mathrm{~mm}$, acuminate at apex, hairy on the dorsal surface, glabrous ventrally, reddish-brown. Flowers resupinate, sepals and petals greenish-brown to greenish-red, labellum white flushed yellow on the outer surface of the mesochile and along the flanges, the spur flushed green; pedicel and ovary 12-16 × 3-5 mm, covered with glandular hairs; dorsal sepal broadly elliptic, 6-6.5 × 4.3-4.5 mm, tapering at both ends, acuminate at apex, forming a hood with the petals above the column, hairy with glandular hairs on dorsal surface, glabrous ventrally; lateral sepals obliquely ovate, 7.5-8 × 4-4.5 mm, acute, hairy with glandular hairs on dorsal surface, glabrous ventrally, semi-transparent to whitish along the lower margins; petals obliquely ovate, appressed to the margins of the dorsal sepal, 6-7 × 3-3.5 mm, acuminate and $\mathrm{Y}$-shaped, hooked at the apex, apical margins slightly revolute, glabrous, semitransparent; labellum spreading and projecting downwards, adnate to the base of the column, 17$19 \times 12-14 \mathrm{~mm}$ including the spur, 3-partite; hypochile flabellate when flattened, $2.5-3 \times 1.5-2$ $\mathrm{mm}$, lateral margins rolled upwards, terminating in a pair of short, ovate-triangular auricles; mesochile canaliculate, $4.5-5 \times 3-4 \mathrm{~mm}$, margins raised, flanged on either side, each flange somewhat fleshy and divided into up to 8 teeth, each tooth 0.2-5.5 mm long; epichile 2-lobed, lobes narrowly elliptic, diverging, $8-9 \times 2.5-3 \mathrm{~mm}$, obtuse; spur conical, 2.5-3 × 2.4-2.6 mm, pointing backwards, conspicuously longitudinally channeled along the external surface, with one oblong callus (on either side) attached to the inner wall, callus up to $2 \mathrm{~mm}$ long, attached only at the centre. Column ovoid,
2-3 × c. $2 \mathrm{~mm}$. Pollinarium Y-shaped, c. $3.5 \times 2$ $\mathrm{mm}$; lobes obovate, arched inwards, $2-2.5 \mathrm{~mm}$ long; caudicle bifurcated into two elliptic lobes, $c$. $2.5 \mathrm{~mm}$ long; viscidium longitudinally 2-lobed, $1-$ $1.5 \mathrm{~mm}$ long, larger lobe obovate, shorter lobe obovate to sagittate. Anther-cap 2-lobed; lobes obovate, $2.6-2.8 \times 2.2-2.5 \mathrm{~mm}$, semi-transparent, yellow, beaked at the front, lobes held together by a semi-circular disc at the top; disc 2-2.2 × 2.6-2.7 $\mathrm{mm}$, base cordate, margins minutely erose.

Flowering: Flowering from October to November.

Habitat: Grows in leaf detritus on mossy boulders, close to streams in mature montane forest.

Distribution: China (Hong Kong only), Japan (Ryukyu Islands) and Taiwan (central mountains and Lanyu Island). The determinations of many specimens held at TAIF and PE are doubtful, and specimens are missing from several sheets; these vouchers are therefore omitted from the list of specimens examined below. Refish et al. (2015) cited one dubious record for Mainland China (Fujian Province), although the species was not listed by either Chen et al. (2009) or Zhou et al. (2016). Similarly, Ket et al. (2004) record the species in Vietnam (Lamdong Province), although it is not listed in any recent enumerations of the orchid flora of Vietnam (Averyanov \& Averyanova, 2003; Govaerts et al., 2020).

Specimens examined: CHINA, Hong Kong, New Territories, Tai Po, 12.11.2019, P. Kumar 12215 (KFBG). JAPAN, Okinawa Prefecuture, Ishigaki-jima, Omoto-dake, 27.11.1957, T. Amano 7736 (RYU); Ibid., 27.12.2003, M. Yokota s.n. (RYU); Ishigaki-jima, Fukaiomoto-dake, 24.12.2016, M. Yokota s.n. (RYU); Iriomote-jima, Goza-dake, 17.08.1966, Y. Miyagi 3566 (RYU); Okinawa-jima, Iyu-dake, 24.11.2013, M. Yokota s.n. (RYU). TAIWAN, Hualien County, Yanhai log road, 19.08.1988, S.Y. Lu 23797 (TAIF); Changchun Temple, 13.12.2006, S.W. Chung \& C.W. Lin 9187 (TAIF); Hualien Hsien, 150-400 m, 26.01.1989, C.I. Peng 12343 (HAST!); Tatung Tribe, 800-1000 m, 03.12.2011, T.C. Hsu 5138 (TAIF). Hsinchu County, Hsinchu Nanzhuang, 
01.09.1914, S. Sasaki s.n. (TAIF); Keelung, Nuannuan, Dandan, 27.11.1938, G. Masamune 3743 (TAI); Mt. Chungcheng, 06.11.2006, T.C. Hsu 644 (TAIF); Mt. Kaopu, 300-400 m, 01.11.2011, T.C. Hsu 4937 (TAIF); Pingtung, Tachienshihshan, 20.10.1990, T.C. Huang, S.F. Huang \& M.J. Wu 14890 (TAI); Shuli County, Mt. Taiheizan, 28.07.1928, S. Suzuki 1125 (PE); Wufong, 700-800 m, 02.10.2014, T.C. Hsu 7339 (TAIF). Taipei City, Chihtanshan, 22.10.1933, I. Simozawa 1126 (TAI); 825 m, 19.10.1992, C.C.Liao 751 (HAST); Chingshan nursery, $600 \mathrm{~m}$, 03.11.1997, K.C. Yang \& W.L. Chiou s.n. (TAIF); Chulushan, Tiirokuzan, 900 m, 06.11.2010, s.coll. s.n. (TAI); Yunshen Water Fall, 500 m, 20.10.2011, s.coll. s.n. (TAI). Taitung County, Lichia Logging Trail, 06.10.2014, H.C. Hung 489 (TAIF); Mt. Kueina, 27.11.2008, T.C. Hsu 2038 (TAIF); Mt. Tulan, 700-900 m, 23.11.2011, T.C. Hsu 5109 (TAIF).

Conservation status: Anoectochilus formosanus was originally described from Taiwan (Hayata, 1914; Chen et al., 2009) and subsequently found in the southern Ryukyu Islands of Japan (Garay \& Sweet, 1974; Iwatsuki et al., 2016). More recently, it has been discovered on Okinawa Island and here we add Hong Kong in continental East Asia to the species' range. It is difficult to estimate population size for Taiwan (where it occurs throughout the central mountains) and Japan (where it is known from Ishigaki, Iriomote and Okinawa islands), since data are lacking. The Hong Kong population comprises a single site known to the authors, although local orchid enthusiasts have claimed the occurrence of more individuals elsewhere. Despite being reported from China (Refish et al., 2015) and Vietnam (Ket et al., 2004), the species was not included by either Chen et al. (2009) or Zhou et al. (2016) in their accounts of Chinese Orchidaceae, and Leonid Averyanov (pers. comm.), a leading expert on the flora of Vietnam, doubts its occurrence in Vietnam. Like $A$. roxburghii, $A$. formosanus is collected for its purported medicinal and ornamental value (Garay \& Sweet, 1974; Shiau et al., 2002; Barretto et al., 2011) and is thereby threatened with local extinction. Indeed, the single known population on Okinawa Island has been entirely extirpated by collectors (M. Yokota, pers. comm.). Excluding the doubtful mainland Chinese and Vietnamese records, the species' Extent of Occurrence (EOO) and Area of Occupancy (AOO) are calculated as $229,846 \mathrm{~km}^{2}$ and $192 \mathrm{~km}^{2}$ respectively, using $2 \times 2 \mathrm{~km}$ grid in GeoCAT (Moat, 2007). The latter may qualify the species for a status of Endangered under Criterion B, but we infer the occurrence of more than 40 sites and there is no evidence to suggest these populations are severely fragmented, or that the species has undergone extreme fluctuation in any population parameter. However, given the ongoing threat of collection, and both observed and projected decline in the species' EOO, AOO, number of subpopulations and number of mature individuals, we consider the species to be Near Threatened following IUCN guidelines (IUCN, 2019).

Notes: Anoectochilus formosanus is easily distinguished from A. roxburghii on account of its dark green leaves with silvery-white venation, resupinate flowers and yellowish labellum with fleshy flanges, short spur (2.5-3 mm long) with oblong calli and rounded spur-apex; in contrast, the latter has brownish leaves with golden venation, erect, double-resupinate flowers and a white labellum with filamentous flanges, long (9-14 mm long) spur with warty calli and bilobed spur-apex. However, when dried and pressed as herbarium specimens, the leaves of both species tend to turn black or brown and the mesochile flanges of both shrink and become filamentous, making it very difficult to differentiate the two. We searched for the type specimen among the material deposited in the Taiwanese herbaria but without success, and it is apparently not to be found at TI either ( $\mathrm{T}$. Yukawa, pers. comm.). There may therefore be a need to neotypify. However, because more effort should first be put into locating the holotype, or into selecting a suitable neotype in the event that the holotype is confirmed as lost, we refrain from doing so here. 


\section{Acknowledgements}

We are thankful to Jenny Lau (AFCD, Hong Kong S.A.R.) for granting permission to collect specimens for study, to Leonid Averyanov (LE, Russia) for fruitful discussion on the taxonomy of Anoectochilus, and to Tomohisa Yukawa (TNS, Japan) and Masatsugu Yokota (RYU, Japan) for sharing information about the species in Japan.

\section{Literature Cited}

AVERYANOV L.V. \& A.L. AVERYANOVA 2003. Updated checklist of the orchids of Vietnam. Vietnam National University Publishing House, Hanoi. p. 101.

BARRETTO G., CRIBB P. \& S.W. GALE 2011. The wild orchids of Hong Kong. Natural History Publishers, Borneo. p. 697.

CHEN X., GALE S.W., CRIBB P.J. \& P. ORMEROD 2009. Anoectochilus. In: WU Z.Y., RAVEN P.H. \& D.Y. HONG (eds.), Flora of China. Volume 25 (Orchidaceae). Science Press, Beijing \& Missouri Botanical Garden Press, St. Louis. pp. 491-498.

DUNN S.T. \& W.J. TUTCHER 1912. Flora of Kwangtung and Hong Kong (China) being an account of the flowering plants, ferns and fern allies together with keys for their determination preceded by a map and introduction. Bulletin of Miscellaneous Information (Royal Botanic Gardens, Kew), Additional Series 10: 1370. https://doi.org/10.5962/bhl.title.57063

GALE S.W., BIZID A., WAI L.K. \& K. CHAN 2014. A Guide to orchids of Hong Kong. Natural History Publications (Borneo), Kota Kinabalu. p.168.

GARAY L.A. \& H.R. SWEET 1974. Orchids of southern Ryukyu Islands. Harvard University Press, Cambridge. p.180.

GOVAERTS R., BERNET P., KRATOCHVIL K., GERLACH G., CARR G., ALRICH P., PRIDGEON A.M., PFAHL J., CAMPACCI M.A., BAPTISTA D.H., TIGGES H., SHAW J., CRIBB P., GEORGE A., KREUZ K. \& J. WOOD 2020. World checklist of Orchidaceae. Facilitated by the Royal Botanic Gardens, Kew. Available at: http://apps.kew.org/wcsp/ (Accessed on 25.02.2020).

HAYATA B. 1914. Icones plantarum formosanarum nec non et contributiones ad floram formosanam Volume 4. Bureau of Productive Industry, Government of Formosa, Taihoku. p. 264. https://doi.org/10.5962/bhl.title.24988

HERKLOTS G.A.C. 1937. Hong Kong Orchids: First Twenty.
Hong Kong University Press, Hong Kong. p. 62.

HU S.Y. 1977. The genera of Orchidaceae in Hong Kong. The Chinese University Press, Hong Kong. p. 160.

IUCN 2019. Guidelines for Using the IUCN Red List Categories and Criteria. Version 14. Prepared by the Standards and Petitions Committee. Available at: http:// www.iucnredlist.org/documents/RedList Guidelines.pdf.

IWATSUKI K., BOUFFORD D.E. \& H. OHBA 2016. Flora of Japan. Volume IVb. Kodansha Ltd., Tokyo. p. 335 .

KET N.V., HAHN E.J., PARK S.Y., CHAKRABARTY D. \& K.Y. PAEK 2004. Micropropagation of an endangered orchid Anoectochilus formosanus. Biologia Plantarum 48(3): 339-344.

KUMAR P., GALE S.W., KOCYAN A., FISCHER G.A., AVERYANOV L., BOROSOVA R., BHATTACHARJEE A., LI J.H. \& K.S. PANG 2014. Gastrochilus kadooriei (Orchidaceae), a new species from Hong Kong, with notes on allied taxa in section Microphyllae found in the region. Phytotaxa 164(2): 91-103. http:// dx.doi.org/10.11646/phytotaxa.164.2.3

MOAT J. 2007. Conservation assessment tools extension for Arc View 3.x, Version 1.2. GIS Unit, Royal Botanic Gardens, Kew. Available at: http:// www.rbgkew.org.uk/gis/cats (Accessed on 09.02.2020)

REFISH N.M.R., FU C.H. \& M.G. WANG 2015. Comparative study of the chemical components of Anoectochilus roxburghii and Anoectochilus formosanus tissue culture. International Journal of Life Sciences Research 3(2): 81-87.

REICHENBACH H.G. 1855. Orchideae hongkongenses. Bonplandia 3: 249-250.

SHIAU Y.J., SAGARE A.P., CHEN U.C., YANG S.R., \& H.S. TSAY 2002. Conservation of Anoectochilus formosanus Hayata by artificial cross-pollination and in vitro culture of seeds. Botanical Bulletin of Academia Sinica 43: 123-130.

SIU G. 2000. Orchidaceae of Hong Kong. Memoirs of the Hong Kong Natural History Society 23: 137-148.

SU H.J. 2000. Orchidaceae. In: HUANG T.C. (ed.), Flora of Taiwan. Volume 5. National Taiwan University, Taipei. pp. ${ }^{729-1086 .}$

ZHOU X., CHENG Z., LIU Q., ZHANG J., HU A., HUANG M., HU C. \& H. TIAN 2016. An updated checklist of Orchidaceae for China, with two new national records. Phytotaxa 276(1): 001-148. httpV.// dx.doi.org/10.11646/phytotaxa.276.1.1 